\title{
Exploring (and Contesting) Literary Knowledge: Pedagogy, Agency and Cultural Capital
}

\author{
John Yandell \\ Institute of Education \\ University College London \\ London, UK \\ j.yandell@ucl.ac.uk
}

\begin{abstract}
Authoritative voices in the Anglophone world have interpellated teachers as responsible for the transmission of an already-fixed canon: their task is thus conceptualised as both providing their students with access to such knowledge and inculcating in their students an appropriate attitude of appreciation towards the already-valorised literary works. Recent research in Australia and England suggests that some teachers, at least, are able to represent their work somewhat differently. This paper will explore these alternative conceptions of literary knowledge and pedagogy.
\end{abstract}

Keywords: Literary Knowledge, Pedagogy, Agency, Cultural Capital

\section{INTRODUCTION}

I want to open up debate in relation to literary knowledge and how it might be seen to be in play in literature classrooms. My interest is in the everyday creativity of literature classrooms, of the students and teachers who populate them, and in the innovation that is to be seen in the remaking of texts as they are remade with each new reading (cf. Doecke \& McClenaghan 2011; Doecke et al. 2014; Yandell 2013). I draw on interview data collected as part of a larger research project investigating teachers' literary knowledge. ${ }^{\mathrm{i}}$ Here, I focus on two mid-career teachers, Hannah and Nurjahan, ${ }^{\mathrm{ii}}$ both of whom are working in London schools.

My starting-point is, therefore, a particular context for literature teaching. I recognise that there are ways in which England might legitimately be regarded as a special case (and some of this might become apparent in what follows). But there are also important commonalities across countries and jurisdictions. Neoliberalism is a global phenomenon, and its effects have been felt profoundly by teachers in many different parts of the world, reshaping pedagogic identities, relationships and purposes through the standards-based reforms and reconstituting schools and universities as sites of marketization and commodification (Apple 2001; Ball 2012; Hutchings 2015). How literary knowledge is construed is not neatly separable from these wider forces. But, as I hope to show in this paper, it would be a mistake to draw the conclusion that teachers of literature and their students have been deprived of agency, reduced to mere units of production in the output-driven system of schooling in which they find themselves. One of the means whereby neoliberalism has sought to reconfigure the terrain of education is by rendering invisible those aspects that are not reducible to the calculus of outcomes and high-stakes tests (Unwin and Yandell 2016). Part of our task, therefore, is to reassert the significance of these aspects, rendering them visible by focusing attention on the day-to-day and moment-by-moment lived experiences of teachers and students in literature classrooms.

\section{INSTITUTIONAL POWER AND THE INDIVIDUAL TEACHER}

One way of exploring what is meant by literary knowledge is to look at the discourse of policy.

Through literature, students have a chance to develop culturally and acquire knowledge of the best that has been thought and written .... GCSE specifications in English Literature should enable students to ... appreciate the depth and power of the English literary heritage ...Students should study a range of high quality, intellectually challenging, and substantial whole texts in detail. These must include:

- at least one play by Shakespeare

- at least one $19^{\text {th }}$ century novel

- a selectionof poetry since 1789 , including representative Romantic poetry

- fiction or drama from the British Isles from 1914 onwards.

- All works should have been originally written in English.

(DfE 2013, 3-4; cf. Arnold 1869/1993) 
So, for example, the current version of the national curriculum in England positions texts, teachers and students in particular ways. Like any curriculum, it involves processes of exclusion and inclusion: it is a selection from what is available, placing some entities at the centre and others at the margins. This version is strongly marked by an insular, narrow, cultural conservatism. It might be suggested that there is a tension, at the very least, between the Arnoldian claim of the first bullet point, that the literature classroom is a place where students 'acquire knowledge of the best that has been thought and written, and the insistence, in the final bullet point, that all works studied 'should have been originally written in English'. It is worth dwelling on this tension for a moment. In its original context, in the debates about culture in mid-nineteenth century Britain, Arnold's argument for the civilising value of literature involved a far more ecumenical sense of the field of literature than this limiting clause now permits. The absolute refusal to permit engagement with literature in translation is all the more perverse in the context of twenty-first-century realities: both the frequency with which readers beyond the classroom encounter texts in translation and the simple fact that the classrooms in which this edict is to have effect are, to a very large extent, classrooms constituted in linguistic and cultural diversity. The emphasis on a narrowly-defined canon of English literature might be construed as the curricular equivalent of Brexit - a retreat from engagement with a wider cultural and social world into the dubious nostalgia of little England. Our students are thus to be given a diet of Shakespeare, Romantic poetry, and nineteenth-century (British?) novels: Dickens, not Dostoevsky;Stevenson, but not Stendhal.

This version of a national curriculum involves more, though, than the specification of a canon. It presents literary educationas the acquisition of a static, already-specified body of knowledge, and it spells out the relation between student and text, since the purpose of exposing learners to the canon is to engender in them the proper attitude of veneration: they are to appreciate the 'depth and power' of the heritage of which they are the fortunate beneficiaries. By implication, the role of the teacher is thus merely to provide their students with access to the cultural goods that are to be found in these texts. There is precious little room here for any more dialogic understandings of educational processes: this is, in a very stark form, a banking model of schooling (Freire 1972).

How the provisions of the national curriculum are operationalised is through the syllabuses drawn up by the examination boards. Here is Hannah, one of the teachers whom I interviewed last year, reflecting on her reaction to the selection of texts offered on these syllabuses:

I was a bit annoyed about the selection of GCSE texts because we're doing Lord of the Flies, Jekyll and Hyde, Romeo and Juliet and... well that's it actually isn't it? And ... in all of that there's the nurse, there's Juliet and there's the maid that witnesses the murder of Carew in Jekyll and Hyde, and other than that... there's no significant female parts or characters, and then ... and further to that, no trace of any kind of ethnicity or multiculturalism in it at all.

... I love Steinbeck and I love Golding and I think they're fantastic writers, but even in Steinbeck ... the only female or black characters are incredibly marginal, don't have proper names, and I think there's a problem ... with just constantly reasserting white men as the authority, and ... I just find it unbelievable that in the twenty-first century we have to teach these texts. And in the new curriculum ...even Lord of the Flies is an imperialistic text ....

(Hannah, interview, 31 May 2016)

Hannah communicates her anger at the processes of exclusion that are so marked in this curriculum. Informing her response is a well-worked-out theoretical position. She draws on a set of ideas about representation (ideas that elsewhere in the same interview she traces back to her own undergraduate degree programme, in the course of which the modules that she took on African American and Irish literature enabled her to problematize not only notions of canonicity but also the relation between culture and imperialism) to produce a powerful critique of the selection from the culture that has been made by the exam boards, following the imprimatur of the national curriculum.

I want to suggest something about what is going on here. In making this critique, Hannah is reclaiming the space that the national curriculum seeks to deny her: speaking back to power through her analysis of the curriculum, she is refusing to be complicit in the exclusions that it enacts. Her analysis of those exclusions involves a reinsertion of the crucial question of representation: who has the right to speak, and on whose behalf are they speaking? Who is represented in a text, and from what perspective? (cf. Spivak1988). These questions, which policy's emphasis on mere acquisition and appreciation seeks to prevent, are thus reinserted into the domain of literary knowledge. But Hannah's frustrations are not only with the cultural conservatism of the policy makers. There are also more local difficulties:

... and the reason we ended up choosing those texts was on sort of practical grounds which no-one would budge on, which was very frustrating. So Jekyll and Hyde is obviously very short and Lord of Flies we had a scheme of work on already and we'd taught it before. So the fact that there were no women in either of these texts was pushed to one side because of those practicalities, and because Lord of the Flies was quite long in GCSE literature terms, we couldn't choose something like Jane Austen or Jane Eyre or the Brontës. So it was one of those ridiculous practical decisions that always happens with the GCSE curriculum.

(Hannah, interview, 31 May 2016)

Within the parameters of the national curriculum and the even tighter constraints of the exam board specifications, there are the decisions made at departmental level about the texts that will be studied. And here, commitments to plurality of 
representation are in competition with less principled, but nonetheless vitally important, considerations. How much content is to be 'delivered', and much time will this take? How long is this text? What resources are already available for teaching it?

And there on the horizon, influencing these decisions about course planning but also shaping the moment-by-moment judgements involved in teaching these texts, is the high-stakes exam by which the students (and their teachers) will be judged. What the curricularisation of literature looks like is thus determined by the way that literary knowledge will be assessed. And this, too, as Hannah observes, involves processes of exclusion and misrecognition:

\begin{abstract}
... the story gets lost in all of the key words and everything we're meant to teach them, and the assessment objectives they're meant to know, and sometimes you look at a scheme of work and the story isn't even there with all the context and everything, and the very centre of it ... that ability to step back and think about the bigger ideas in it and see it as a whole is quite... I don't think we necessarily do enough of it. I think we focus too much on the individual words sometimes.
\end{abstract}

(Hannah, interview, 31 May 2016)

We'll return to Hannah in a while. Before we do, though, I want to zoom in much closer to consider a moment in a literature classroom, since, no matter how detailed and prescriptive the curricular policies and plans may be, they are never sufficient to describe, or account for, the enacted curriculum (Barnes 1976). Here, I am drawing on an interview with a different teacher, Nurjahan, and her story of how one of her students responded to a poem. The poem she had presented to her class was 'Strange Fruit' (Meeropol 1937), made famous through the version sung by Billie Holliday. We - the interviewers involved in the research project - had asked each of the participants to bring to the interview an artefact that was in some way illustrative of their work as literature teachers. The other participants whom I interviewed chose to share materials or curricular resources that they had developed. Nurjahan chose a rather different kind of artefact - an exercise book belonging to Nasim, ${ }^{\mathrm{iii}}$ one of her students. Here is the page from Nasim's bookwhich Nurjahan drew to my attention:

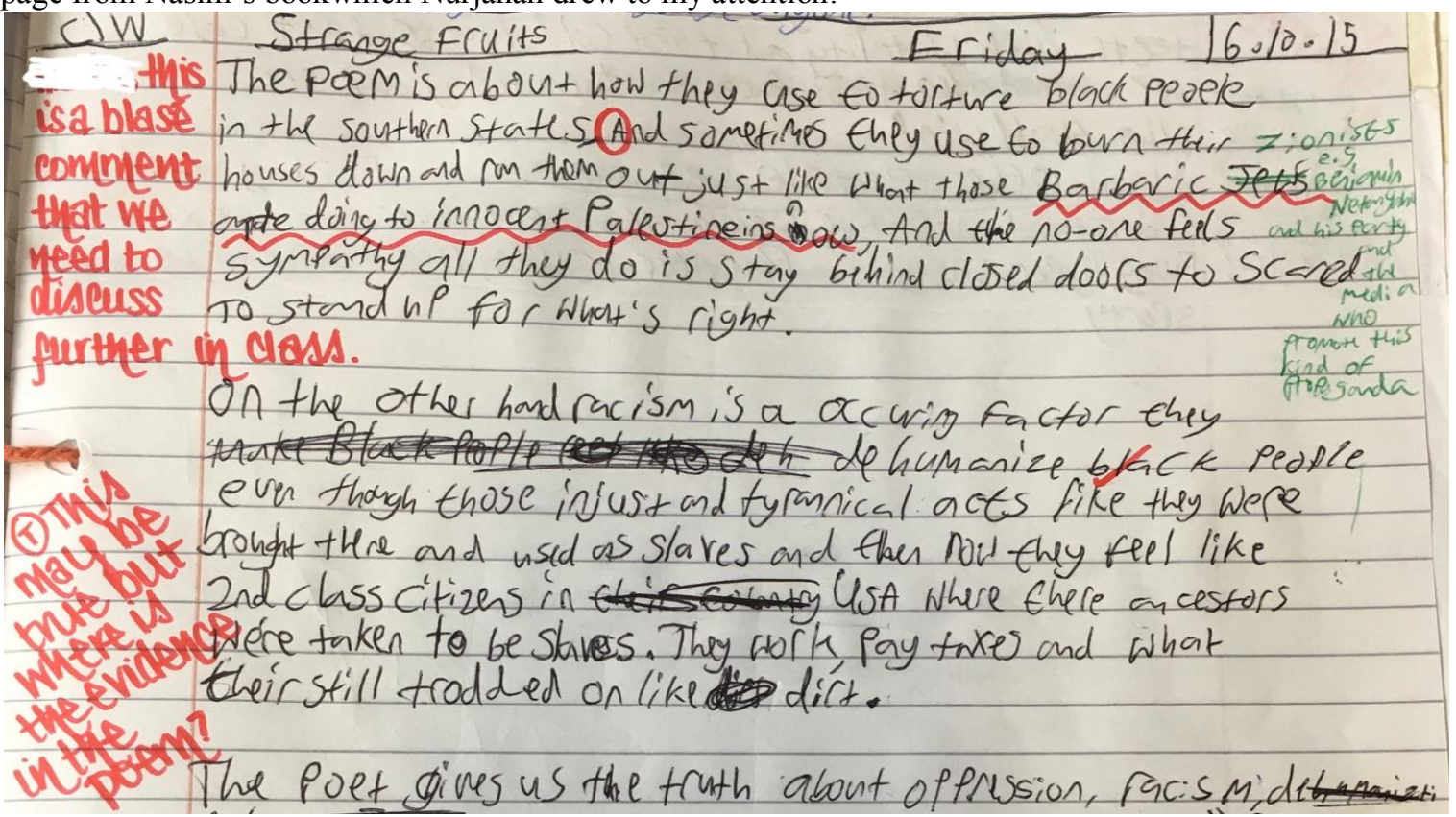

Fig. 1. An Exercise Book belonging to Nasim

Even at first sight, it is clear, I think, that the page has become contested terrain, a site of dialogue, for sure, but not of an entirely harmonious kind. The poem, and particularly Nasim's response to it, is a matter of contention between teacher and student. This is Nurjahan's account of the exchange:

[My students] were meant to write about the extent of metaphor and instead he just went off on a massive rant about how certain cultures are killed when they're innocent, and he ... compared it to Palestinians and ... talked about ... what's happened in Mexico and how Hispanics have been killed and how there's a lot of prejudice in America ... but obviously nothing to do with picking out quotes and analysing language.

And then in the context of my school and the hyperawareness of radicalisation, I had to write loads of comments on [his book] and flag it up and say 'look it's not even a safeguarding thing ... and I've talked to him about it'.

... So I marked it according to the school marking policy and I've written questions for him to answer. I wrote: OK, but is there evidence in the poem to support this rant? [laugh]

And his answer to this, in green pen, is: 121 Palestinians were killed since October when the violence began. Where this evidence had come from I've no idea ... and still nothing to do with the poem but you know he's [laugh] given some sort of response to my question 
Nasim has, in effect, been presented with a version of literary study similar to that which Hannah identifies above: under pressure to prepare students for the demands of an exam that privileges the ability to identify and analyse formal attributes of the text, and to employ an appropriate metalanguage in making this analysis (metaphors and similes, lines and stanzas), Nurjahan had set a task that was designed to induct her students into the well-worn procedures of close reading. But Nasim is a resistant reader. What I mean by this is not at all that Nasim is resistant to the act of reading, but that he resists the imperative to produce a particular kind of reading of the text he has been given. Instead, he uses the act of writing to reflect on the meaning of 'Strange Fruit'. He takes the poem seriously enough to think carefully about what it means to him. And this is no merely local (re)reading, in that his reflection takes the poem out of the classroom and back into the world, back into the culture and history from which Nurjahan had abstracted it, in her attempt to reposition it as a curricular object. The questions that Nasim is addressing are questions of representation: what is being represented here, and who is speaking, on behalf of whom? And, in engaging with the poem, he is both engaging with the history that is represented and presenting himself as implicated in this history, as someone who is himself prepared to resist 'injust and tyrannical acts', as he defines them.

In her response to what Nasim has written, Nurjahan encourages her student to perform the act of close reading that he has thus far resisted. 'Is there evidence in the poem?' invites Nasim to leave, at least for a moment, the bigger ideas and to focus attention on the words, to play the game of quotation and textual exegesis. But he continues to resist, as he repositions the demand for evidence, shifting attention from the words on the page to recent events in the world. He justifies his 'rant' (if that is what it is) not by attending to the analysis of the symbolic violence of metaphor but by insisting on the reality of the violence committed by the state of Israel. For Nasim, reading the word and reading the world are not to be separated (Freire and Macedo 1987).

As Nurjahan's account makes clear, what is happening here is framed by powerful institutional forces. All schools in England are subject to scrutiny in relation to the 'Prevent' policy - the attempt by central government to counter the radicalisation of young people by making educational institutions responsible for the monitoring and reporting of any signs of such radicalisation(Home Department 2011; Home Office 2015). For schools like Nurjahan's, where a large percentage of the student population are Muslim, this scrutiny is particularly intense. As she indicates, her response to Nasim's writing is inflected by her awareness of this surveillance: she needs to mark his book in such a way as to reassure those who might scrutinise it, and her practice as a teacher, that nothing untoward is occurring here, that the situation is under control and that no-one need take any further interest in Nasim. Nurjahan is thus seeking to protect Nasim, as well as herself.

I would also want to suggest that Nurjahan's identity as a Muslim is salient, in two somewhat distinct ways. First, in a way that is perhaps more apparent in her telling of the story, it makes her more aware of the need to protect Nasim, more aware of the real possibility that his interest in the world will be misconstrued by others and therefore of the desirability of reframing his writing as a close reading of the poem. Second, I think it is plausible that what Nasim has written has been produced with Nurjahan very clearly in mind as the reader of this 'rant'. Nasim knows that Nurjahan will be a sympathetic reader, one who will take his views seriously, and will take seriously his right to read the world as well as the word. All of this greatly complicates the way I have presented thus far the exchange that happens on the page of Nasim's exercise book. What seems to me to be happening here is that Nurjahan is inhabiting a discourse (the expected teacherly response to Nasim's work) but that this discourse is only one of a number of voices or perspectives informing the dialogue between them. What Nurjahan is conspicuously not doing is silencing Nasim.

And then, of course, there is the fact that Nurjahan chooses to share this moment with me. That needs to be understood in the context of our relationship, just as any interview data need to be interpreted relationally and contingently, as interactions between people (Mishler 1986).So how Nurjahan represents this moment, as well as her decision to represent it at all, needs to be read in the context of this relationship, of her sense of me and of our shared history.

More straightforwardly, too, Nurjahan's choice of text is far from innocent. Although she may, in the way that she set up the written task, have been seeking to develop in her students the kind of response to the text that is valorised in the high-stakes examination that awaits them, she has chosen a poem that invites other responses than the merely formalist. Nasim's reading is an angry one - but he is responding, entirely appropriately, to the sustained anger of the text he has read. The text has interested him, as Nurjahan might have hoped that it would. There is, thus, a doubleness in her response to Nasim's response: as well as concern,there is pleasure that it has, indeed, meant something to him.

\section{ACTS OF REAPPROPRIATION: WHOSE READING COUNT?}

It might appear, from what I have explored thus far, that the agency of teachers is to be located in the selection of texts to be read in class. 'Strange Fruit' is Nurjahan's choice, and it is a choice that enables students like Nasim to find a space for himself in the literature classroom, and a way to bring his interests in the world beyond the classroom into a productive relationship with his reading. What emerges very strongly from the interview data, however, is that there is scope for different kinds of engagement, even where the text is imposed on teacher and student alike. There are, in other words, different ways of reading, and different pedagogies that can enable these to flourish. 
[Our introduction of critical perspectives] is an effort to get the students into the habit of challenging the canon rather than accepting it as a canon. And so the idea of [this approach is] to challenge and say well are the women in there, and that's a perfectly legitimate question to ask, rather than feel like these are the authority ... the idea is that they are just a framework for the students to interrogate a text that we give them

(Hannah, interview, 31 May 2016)

In her interview, Hannah talks of her department's decision to introduce students to a range of critical perspectives feminist, Marxist, post-colonial.As she suggests, the effect of this is to position her students differently. Rather than being expected to accept the authority of the canon, to learn to appreciate the 'depth and power' of the heritage, they are given the power to interrogate the text with which they are confronted, to question its absences and its suppressions.

In discussion with her colleagues, Hannah had wanted to develop this further by, in effect, problematizing the status of the text:

So one of the ideas ... that I had was to start them off with kind of that idea that the text doesn't have meaning until it's completed by them as readers and give them a kind of active book, but it was dismissed when someone said it would be too complicated ... whereas really, what it is then, you were thinking about the context of production and then the context of reception and really how they as readers interpret the texts, and what they find interesting or surprising about how any part of society is presented in it, and how they interpret it in that way

(Hannah, interview, 31 May 2016)

The idea isn't, of course, a new one (Rosenblatt 1978; Iser 1978; Jauss 1982; Barthes 1977), butthe response of Hannah's colleagues is interesting. For them, it would appear, the array of other critical theories which they were happy to share with their students provided a set of analytical tools with which to approach or dissect the text, without challenging the text's integrity as the repository of stable meaning. Hannah's proposal of what might be termed a reader response approach, on the other hand, seems 'too complicated' precisely because it involves a fundamental realignment, locating meaning not in the text but in the readers' interactions with that text, and thus shifting the focus much more towards the (necessarily different) contexts of reception that might frame such acts of meaning-making.

For Hannah, what is at stake here is not just a question of which brand of literary theory one happens to favour but rather of the overarching rationale for the subject, whether that is called English, or literary study, or language arts, or something else. Her rejection of the cultural conservatism of the new curriculum is thus not an argument, primarily, about text selection but about the notion of authority that is enforced through the imposition of the canon. In opposition to this version of curriculum, which carries with it an assumption of an equally authoritarian pedagogy of transmission (cf. Furedi 2006), Hannah offers a much more democratic, participatory and dialogic version of English teaching:

I feel that the new curriculum is just really instating an old model of authority - the imperial and patriarchal ... but, for me, the teaching of English isn't about that ... actually it's just reading things and talking about them, and it seems like almost like a hobby rather than an actual subject or anything like that, but reading a text and discussing it ... and thinking about the values and the ideas in it ... your ideas about who you are and what society is - that's really what you're doing in English at university and really down to key stage 3

(Hannah, interview, 31 May 2016)

As Hannah expands on her version of English, she communicates, very strongly, the sense of what it is like to be in her classroom. There is an attentiveness to what the students bring to the lesson, to the importance of their own experiences and of how these are realised in and reworked through the stories they tell:

... a lot of it is stories, and you know so much of what you do is you read a story and then you almost, in understanding that story, students tell a story. So they'll say when I was ..., and then they go off and say something and it seems totally mad, but it's not, and ... there's always this kind of backwards and forwards between those things, and I think... and that is so important to them in lots of levels because it's the sort of talking about those stories that enables them to be able to write about ... even it's testing out their ideas, and sometimes they change their minds you know, and I think... actually it's about them, and ... I think it's a lot about them realising that their experience or ideas matter.

(Hannah, interview, 31 May 2016)

Like Hannah, Nurjahan is committed to an approach to literature that is predicated on positioning students as active makers of meaning. In this, texts become tools for thinking with and reading becomes a means of making sense both of ourselves and of the world:

I just like [my students] to enjoy texts as much as I did, and realise that these texts enable us to make sense of the world and understand what's going on around us, and to work out your own identity within that world. 
... talking about that with kids is interesting, that's why I teach English. I want it to be personal to them, I don't want it to be about my experiences superimposed on them, I don't want it to be Steinbeck's experiences superimposed on them. I want them to look at the text and try and work out, well this kind of stuff I can relate to or I can't relate to, and this is what is important to who I am or who I am going to be one day.

What's interesting to me is students struggling through what literature is and making sense of it ... [similar to how we] approach literature when we're older - we read it because there's a voice there that we want to listen to, or there's a voice there that is in tune with our own

(Nurjahan, interview, 7 June 2016)

Reappropriation of the canon involves breaking down barriers - between school and home, between reading and writing, reception and making, and between teachers and students:

I don't particularly like Dickens - I find him quite preachy, I don't like having morals shoved down my throat, but we're doing it with a low ability group and they're really enjoying it, and they like the gothic tropes, and a scary ghost coming out ... yesterday, they watched a clip and they were so excited, they were screaming and laughing ... just to see a bunch of students who are completely uninterested in the gravitas of literature and why children should learn literature, just genuinely having fun ... I want them to enjoy what they're doing and go, oh yeah there was that English lesson where we had a look at that miser, perhaps I should give some money to some charity [laugh].

... I like teaching canon, I like what students do with it, but I enjoy it so much because it's a process of reappropriation for me. It's more about them taking ownership of that, so it's not about stuffy middle class dead white men, it's about ... a Sri Lankan boy or an Indian boy or a Somali girl ... it's just a lens through which we can see the world

(Nurjahan, interview, 7 June 2016)

\section{The Place of Pedagogy: Classrooms as Dialogic Spaces}

In the discourse of policy, the function of the literature curriculum is explicitly to promote the students' acquisition of cultural capital. This is a project which owes an obvious and acknowledged debt to E.D. Hirsch (Hirsch 1987, 1996, 2006; cf. Gibb 2015; Yandell 2017). Literature is the repository of powerful knowledge, to be acquired by students as they learn to appreciate the canon.

But if, in this model, literature is the cultural capital to be acquired, the problem that confronts the teacher is that the reading of canonical texts is facilitated by the prior possession of (the right sort of) cultural capital. All reading is intertextual, allusive. It is easier to read a text if one already has a familiarity with the cultural hinterland, the web of references and allusions, that enables one to situate the text.

Hannah recognises, though, that her students are very differently positioned in relation to the knowledge that the canon both offers and requires. (This is where Hirsch and his supporters enter the argument: their remedy is to provide those without the capital with extra injections of knowledge.) Hannah explores this difference by comparing two of the classes she teaches. In one, where the students are predominantly middle class, the students tend to arrive with plentiful prior knowledge of a text; in the other, where students are almost all from working class backgrounds, the situation is very different. As she talks about this, though, Hannah qualifies the comparison, and it is here that she marks a decisive break with the Hirschian analyis. It is, she reflects, at least as much a question of confidence as it is of knowledge:

... they [the middle-class students] just knew a lot of stuff really, lots of different... So if you make a reference, you could assume that most of them would at least have an idea of what you were talking about, whereas... but the other thing that is interesting is the confidence in that class too compared to the other class.

So if I said... if I said have you heard of Frankenstein to the other class[consisting of working-class students]... they might have heard of it but they would be sort of thinking, am I going to put my hand up because is she going to make me tell her something about it, and I don't know really. I've heard of it but...

(Hannah, interview, 31 May 2016)

Then, towards the end of the interview, Hannah makes a remarkable move. Resisting the Hirschian temptation to ascribe deficit to her working-class students, she acknowledges that the difference is not in the possession or lack of cultural capital, but rather in the degree of congruence between the students' funds of knowledge and the teacher's (cf. Brice Heath 1983; Moll 1994; Gonzales et al. 2005; Yosso 2005):

I've got a Kurdish boy call Kashwar and he might make reference to something that I don't know about, and then they might have a conversation across the classroom about it, and I feel totally excluded and completely ill-equipped to help there because I think, well I don't know if that connection is ... so I have to say explain to me what you're talking about, then it's this whole strange situation where I have to try and ... I'm like shut out of this world that they... and I know all of this stuff but I don't know that stuff, and that's what they feel the other way around probably ... but that's a really valid moment in the classroom, and they are drawing on the ir own understanding of stories or something, even if it's in music or anything like that or films that they've seen or programmes, it happens, 
and in some ways I think it sometimes happen more in that classroom than in my other one because they are looking for the established connections already, so they know, they've been told like Frankenstein, Jekyll and Hyde, drawing where they fit into this box together, so make your connections there, don't make it to Jessie J or whatever you're thinking of ....

(Hannah, interview, 31 May 2016)

The issue, then, is not whether reading the canon is a creative, intertextual process, whereby the text is freshly remade on each reading; it is, whether we, like Nurjahan and Hannah, are prepared to recognise the different funds of knowledge that learners possess and whether we are prepared for them to read the canon on their own terms.

\section{References}

Apple, Michael W. (2001). "Markets, Standards, Teaching, and Teacher Education." Journal of Teacher Education 52 (3):182196.

Arnold, Matthew. (1869/1993). Culture and Anarchy and other writings. Cambridge: Cambridge University Press.

Ball, Stephen J. (2012). "The reluctant state and the beginning of the end of state education." Journal of Educational Administration and History 44 (2):89-103. doi: 10.1080/00220620.2012.658764.

Barnes, Douglas. (1976). From Communication to Curriculum. Harmondsworth: Penguin.

Barthes, Roland. (1977). Image Music Text. Translated by Stephen Heath. London: Fontana.

Brice Heath, Shirley. (1983). Ways with Words: language, life and work in communities and classrooms. Cambridge: Cambridge University Press.

DfE [Department for Education]. (2013). English literature: GCSE subject content and assessment objectives. London: DfE. Online at: https://tinyrl.com/od9hnyr

Doecke, Brenton, \& McClenaghan, Douglas. (2011). "Classrooms, creativity and everyday life: a continuing inquiry." In Creating an Australian Curriculum for English: national agendas, local contexts, edited by Brenton Doecke, Parr, Graham, \& Sawyer, Wayne, 35-53. Putney, NSW: Phoenix.

Doecke, Brenton, Parr, Graham, \& Sawyer, Wayne, ed. (2014). Language and Creativity in contemporary English classrooms. Putney, NSW: Phoenix.

Freire, Paulo. (1972). Pedagogy of the Oppressed. Translated by Myra Bergman Ramos. Harmondsworth: Penguin.

Freire, Paulo, \& Macedo, Donaldo. (1987). Literacy: Reading the Word and the World. London: Routledge and Kegan Paul.

Furedi, Frank. (2009). Wasted: why education isn't educating. New York \& London: Continuum.

Gibb, NIck. (2015). "How E.D. Hirsch Came to Shape UK Government Policy." In Knowledge and the Curriculum: A collection of essays to accompany E. D. Hirsch's lecture at Policy Exchange, edited by Jonathan Simons, \& Porter, Natasha, 12-20. London: Policy Exchange.

Gonzalez, Norma, Moll, Luis C., \& Amanti, Cathy, ed. (2005). Funds of Knowledge: theorizing practices in households, communities, and classrooms. Mahwah, New Jersey, \& London: Lawrence Erlbaum.

Hirsch, E.D. (1987). Cultural Literacy: What Every American Needs to Know. Boston: Houghton Mifflin.

Hirsch, E.D. (1996). The Schools We Need and Why We Don't Have Them. New York: Doubleday.

Hirsch, E.D. (2006). The Knowledge Deficit: Closing the Shocking Education Gap for American Children. Boston \& New York: Houghton Mifflin.

Home Department. (2011). Prevent strategy. London: Home Department. Online at: https://www.gov.uk/government/uploads/system/uploads/attachment_data/file/97976/prevent-strategy-review.pdf

Home Office. (2015). Revised Prevent duty guidance: for England and Wales. London: Home Office. Online at: https://www.gov.uk/government/uploads/system/uploads/attachment_data/file/445977/3799_Revised_Prevent_Duty_Guid ance England Wales V2-Interactive.pdf

Hutchings, Merryn. (2015). Exam factories? The impact of accountability measures on children and young people. London: NUT. Online at https://www.teachers.org.uk/files/exam-factories.pdf

Iser, Wolfgang. (1978). The Act of Reading: a theory of aesthetic response. Baltimore/London: Johns Hopkins University Press.

Jauss, Hans Robert. (1982). Towards an Aesthetic of Reception. Translated by Timothy Bahti. Minneapolis: University of Minnesota Press.

Meeropol, Abel. (1937). 'Strange Fruit'.Online at: http://www.metrolyrics.com/strange-fruit-lyrics-billie-holiday.html

Mishler, Elliot G. (1986). Research Interviewing: Context and Narrative. Cambridge, MA, \& London: Harvard University Press.

Moll, Luis C. (1994). "Mediating knowledge between homes and classrooms." In Literacy: interdisciplinary conversations, edited by Deborah Keller-Cohen, 385-410. Cresskill, NJ: Hampton Press.

Rosenblatt, Louise M. (1978). The reader, the text, the poem: the transactional theory of the literary work. Carbondale \& Edwardsville: Southern illinois University Press.

Spivak, Gayatri Chakravorty. (1988). "Can the Subaltern Speak?" In Marxism and the Interpretation of Culture, edited by Cary Nelson, \& Grossberg, Lawrence, 271-313. Urbana, Illinois, \& Chicago: University of Illinois Press.

Unwin, Adam, \& Yandell, John. (2016). Rethinking Education: whose knowledge is it anyway? Oxford: New Internationalist. 
Yandell, John. (2013). The Social Construction of Meaning: reading literature in urban English classrooms. London \& New York: Routledge.

Yandell, John. (2017). Culture, knowledge and power: what the Conservatives have learnt from E.D. Hirsch. Changing English 24.4 (forthcoming).

Yosso, Tara J. (2005). "Whose culture has capital? A critical race theory discussion of community cultural wealth." Race Ethnicity and Education 8 (1):69-91. doi: 10.1080/1361332052000341006.

investigating literary Knowledge in the Making of English Teachers: International Pilot (2015-2016). Larissa McLean Davies (University of Melbourne, P.I.), Brenton Doecke (Deakin University), Andy Goodwyn (University of Reading), Philip Mead (University of Western Australia) Rachael Roberts (University of Reading), Wayne Sawyer (Western Sydney University), John Yandell (University College London), Lyn Yates (University of Melbourne).

${ }^{i i}$ Hannah and Nurjahan are culturally appropriate pseudonyms.

iii Nasim is, likewise, a culturally appropriate pseudonym. 